\title{
Nutritional Studies on Vegetable Soybean [Glycine max (L.) Merrill], in Northern Dryzone of Karnataka, India
}

\author{
Vijayalakshmi Patil*, Shankar Meti, C. P. Mansur, E. Rajashekhara, \\ Itagi Prabhaker, H. P. Hadimani and H. Kaviraja \\ Department of Vegetable Science, College of Horticulture, Bagalkot-587104, Karnataka, India \\ *Corresponding author
}

\author{
A B S T R A C T
}

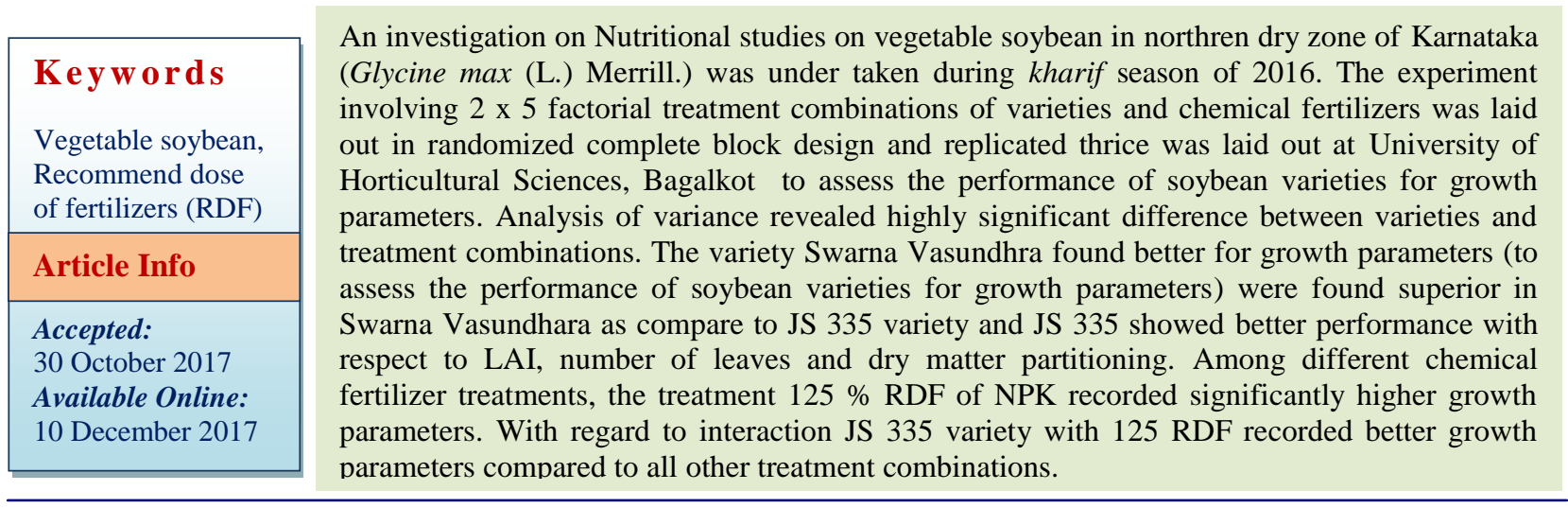

\section{Introduction}

In India protein malnutrition is very common as most of the Indians are mainly vegetarians. To mitigate the protein malnutrition of Indian population, there is a need for versatile crop with high protein content which is suitable for Indian climate and different cropping systems. Vegetable soybean has excellent potential for enriching the human diet and fits well into the Indians diet for supplementing the protein rich food to overcome the protein deficiency in diet. (Keating et al., 2011)

Vegetable soybean [Glycine max (L.) Merrill], belongs to family leguminoceae. Vegetable soybean also known as greensoybean, sweet-beans, maodou and edamame, is large-seeded, sweet flavor, bright green colour, light hilum and soft textured vegetable type. It is valued for its tender 'green-pods' which could be served as snacks, salad-mixes, stir-fried or for 'immature green-seed' that are harvested, slightly before it gets mature and become dry. The seeds of vegetable soybean has some specific consumption quality parameters e.g. green-colour, soft-texture, larger, sweeter, tender seeds with less beany flavour than grain soybean. Such green seeds are commonly used in most countries. Vegetable soybean is rich in protein (13\%), cholesterol-free fatty acids (5.7\%), TSS (6.5\%), phosphorus $(158 \mathrm{mg} / 100 \mathrm{~g})$, calcium $(78 \mathrm{mg} / 100 \mathrm{~g})$, It is a good source of 
carbohydrate and ironrich source of vitamin $A$, vitamin $B_{1}(0.4 \mathrm{mg} / 100 \mathrm{~g})$ and vitamin $B_{2}$ $(0.17 \mathrm{mg} / 100 \mathrm{~g})$. (Shanmugasundaran and Yan, 1999). In addition, it is a natural source of iso-flavones and tocopherols. The nutritional value and protein content is an important characteristic of vegetable soybean, which is superior to the meat, cow milk and eggs. Vegetable soybean provides more protein of higher quality and is considered as excellent protein source compared to vegetable pigeon pea and green peas protein. In addition to domestic consumption, vegetable soybean also has export potential.

Considering this central variety release committee in 2008 has released vegetable soybean cultivar "Swarna Vasundhara" -an elite germplasm lineintroduced from AVRDC, Taiwan. It has green pods that become ready for harvest in 75-80 days after sowing, and are mainly 2 and 3 seeded with 50-55 per cent recovery of shelled bright beans. The farmers have accepted this new vegetable soybean variety for growing as a rainfed Kharif crop in the uplands of eastern India mainly Jharkhand tribal belt and improved the nutritional status of tribal population. There is a need to extend this vegetable soybean into other parts of India. The cultivation practices for vegetable soybean and grain soybean are similar except that vegetable soybean is harvested early when the pods are green.Additional advantage with vegetable soybean is that high value grains $(10 \mathrm{t} / \mathrm{ha})$ can be produced in short period of time (65-75 days) along with highly nutritious stover (30t/ha) which can be used as green fodder for live stocks or as a green manure. In this regard an investigation was conducted to evaluate the performance of vegetable soybean cv. Swarna vasundhara vis a vis seed soybean cv. JS 335 and to find out optimum fertilizer levels under the agroclimatic condition of northern Karnataka.

\section{Materials and Methods}

The present investigation was carried out during kharif season during 2016 at at Main Horticulture Research Station, UHS, Bagalkot. Soybean varieties Swarna vasundhara (vegetable type) and JS 335 (seed type) were evaluated against five levels of fertilizer viz. $125,100,75$ and 50 per cent of recommended dose of fertilizer for seed soybean. Ten treatment combinations were laid out in randomized complete block design (RCBD) with three replications. The two varieties were sown with intra row spacing of $30 \mathrm{~cm}$ and intra row spacing of $10 \mathrm{~cm}$ with standardized package of practices to ensure healthy plant growth. All the recommended agronomic practices and crop husbandry were followed to raise a good crop. Observations were recorded on fifteen labeled plants for growth and yield contributing characters like plant height, number of leaves, number pods per plant, pod fresh weight (g/plant), seed fresh weight (g/plant),correlation, total bio mass yield ( $\mathrm{kg} / \mathrm{ha})$, pod yield $(\mathrm{kg} / \mathrm{ha})$ and seed yield per hectare $(\mathrm{kg} / \mathrm{ha})$. The analysis of variance was calculated by using Panse and Sukhatme (1967) method.

\section{Results and Discussion}

The results of the investigation on the "Nutritional studies on vegetable soybean (Glycine $\max$ (L.) Merrill) in northern dry zone of Karnataka" is presented in this chapter.

Significant differences were observed in growth and yield parameters as influenced by variety and fertilizer levels. The morphological characters like (plant height, number of leaves and leaf area index) differed due to varieties and different nutrient management practices at 30 and 60 days after sowing. 
The plant height at 30 and 60 DAS was significantly influenced by variety and fertilizer levels but their interaction did not show significant effect (Table 1). Among the varieties Swarna Vasundhara recorded significantly higher plant height $(13.35 \mathrm{~cm})$ as compared to JS-335 $(11.92 \mathrm{~cm})$. Among the fertilizer levels, application of 125 per cent RDF recorded significantly higher over other treatments. Enhanced fertilizer level has increased the photosynthetic activity, chlorophyll content in the plants which ultimately improved the plant height and number of leaves per plant. Similar reports of increase in plant height with the application of nutrient combinations as compared to control reported by Cirak et al., (2006), Kumar et al., (2006), Vyas et al., (2007), and Thakur and Girothia (2010). The increased LAI per plant at higher dose may be due to more activities of meristematic tissues of the plant producing more number of trifoliate with increased photosynthetic surface and increased LAI of the plant thus, contributed towards the higher production of branches and also increased dry matter production. These findings are in also agreement with Millholon (1985), Saxena et al., (2013). Interaction between variety and fertilizer level did not significantly influence the plant height and number of leaves per plant at 30 and 60 DAS.

\section{Dry matter distribution in different parts}

Dry matter in leaves, at 60 DAS was significantly influenced by different fertilizer levels but variety and their interaction with fertilizer levels did not differ significantly (Table 2). Among different fertilizer levels, application of 125 percent of RDF recorded significantly higher dry matter in leaves $(8.65$ $\mathrm{g} /$ plant) over other treatments but was on par with 100per cent RDF (7.49g/plant).

Dry matter in stem at 60 DAS was significantly influenced by different fertilizer levels but variety and their interaction with fertilizer levels did not differ significant5366ly (Table 2).

Among different fertilizer levels, application of 125 percent of RDF recorded significantly higher dry matter in stem $(2.4 \mathrm{~g} /$ plant $)$ over other treatments but on par with 100 per cent RDF. Dry matter in root at 60 DAS was significantly influenced by different fertilizer levels and variety but their interaction with did not differ significantly (Table 2).

Among different fertilizer levels, application of 125 per cent of RDF recorded significantly higher dry matter in roots $(1.47 \mathrm{~g} / \mathrm{plant})$ over other treatments at 60 DAS. Among the variety Swarna Vasundhara recorded significantly higher dry matter in root compared to JS 335.

Dry matter in pod at 60 DAS was significantly influenced by varieties, different fertilizer levels and their interactions (Table 2). Among the varieties JS-335 recorded significantly higher dry matter in pod(9.26 g/plant) over Swarna Vasundhara (4.45 g/plant).Among different fertilizer levels, application of 125 percent RDF recorded significantly higher dry matter in pod $(8.32 \mathrm{~g} / \mathrm{plant})$ over other treatments but at par with 100 and 75 per cent RDF. With regard to interaction, application of 125 per cent RDF with variety JS 335 recorded the significantly higher dry matter in pod (11.78 g/plant) as compared to all other treatment combination but on par with 100 per cent RDF with JS 335.

\section{Dry matter distribution in different parts at harvest}

The dry matter in leaves at harvest was significantly influenced by varieties, different fertilizer levels and their interactions (Table 3). Among the varieties Swarna Vasundhara recorded significantly higher dry matter in leaves (4.5 g/plant) over JS-335 (3.50 g/plant) at 75 DAS. 
Table.1 Plant height $(\mathrm{cm})$ and number of leaves/plant at various growth stages as influenced by soybean varieties and fertilizer levels

\begin{tabular}{|c|c|c|c|c|c|c|c|c|c|c|c|c|}
\hline \multirow[t]{3}{*}{$\begin{array}{l}\text { Fertilizer } \\
\operatorname{level}(\mathbf{F})\end{array}$} & \multicolumn{3}{|c|}{ Plant height 30DAS (cm) } & \multicolumn{3}{|c|}{ Plant height 60DAS (cm) } & \multicolumn{3}{|c|}{$\begin{array}{c}\text { No. of Leaves/plant } \\
\text { 30DAS }\end{array}$} & \multicolumn{3}{|c|}{ No. of Leaves/plant 60DAS } \\
\hline & \multicolumn{2}{|c|}{ Variety (V) } & \multirow[t]{2}{*}{ Mean } & \multicolumn{2}{|c|}{ Variety (V) } & \multirow[t]{2}{*}{ Mean } & \multicolumn{2}{|c|}{ Variety (V) } & \multirow[t]{2}{*}{ Mean } & \multicolumn{2}{|c|}{ Variety (V) } & \multirow[t]{2}{*}{ Mean } \\
\hline & $\mathbf{V}_{1}$ & $\mathbf{V}_{2}$ & & $\mathbf{V}_{1}$ & $\mathbf{V}_{2}$ & & $\mathbf{V}_{1}$ & $\mathbf{V}_{2}$ & & $\mathbf{V}_{1}$ & $\mathbf{V}_{2}$ & \\
\hline $\mathbf{F}_{1}$ & 13.81 & 13.97 & 13.89 & 20.32 & 19.21 & 19.77 & 6.22 & 6.14 & 6.18 & 19.69 & 17.11 & 18.40 \\
\hline $\mathbf{F}_{2}$ & 12.33 & 13.78 & 13.06 & 18.48 & 18.17 & 18.33 & 5.75 & 5.14 & 5.44 & 16.64 & 14.51 & 15.58 \\
\hline $\mathbf{F}_{3}$ & 11.74 & 13.22 & 12.48 & 16.26 & 16.62 & 16.44 & 5.28 & 4.08 & 4.68 & 15.09 & 12.49 & 13.79 \\
\hline $\mathbf{F}_{4}$ & 11.25 & 12.67 & 11.96 & 15.82 & 16.47 & 16.14 & 5.06 & 4.06 & 4.56 & 13.73 & 12.73 & 13.23 \\
\hline $\mathbf{F}_{5}$ & 10.49 & 13.13 & 11.81 & 15.52 & 17.84 & 16.68 & 4.17 & 4.36 & 4.26 & 11.64 & 11.73 & 11.69 \\
\hline \multirow[t]{2}{*}{ Mean } & 11.92 & 13.35 & 12.64 & 17.28 & 17.66 & 17.47 & 5.29 & 4.76 & 5.02 & 15.36 & 13.71 & 14.54 \\
\hline & $\mathbf{V}$ & $\mathbf{F}$ & $\mathbf{F} \times \mathbf{V}$ & $\mathbf{V}$ & $\mathbf{F}$ & $\mathbf{F} \times \mathbf{V}$ & $\mathbf{V}$ & $\mathbf{F}$ & $\mathbf{F} \times V$ & $\mathbf{V}$ & $\mathbf{F}$ & $F \times V$ \\
\hline S.Em \pm & 0.22 & 0.35 & 0.50 & 0.27 & 0.42 & 0.59 & 0.21 & 0.33 & 0.47 & 0.59 & 0.93 & 1.32 \\
\hline C.D. $(5 \%)$ & 0.66 & 1.05 & NS & NS & 1.25 & NS & NS & 1.35 & NS & NS & 2.76 & NS \\
\hline C.V (\%) & & 6.84 & & & 5.89 & & & 16.14 & & & 15.67 & \\
\hline
\end{tabular}

NS- Non-Significant, RDF- Recommend dose of Fertilizer (40:80:25:12:20 kg/ha)

Factor I: Varieties

V1- JS-335

V2- SwarnaVasundhara
Factor II: Nutrient management practices

F1-125\% RDF

F2-100\% RDF

F3-75\% RDF

F4-50\% RDF

F5- $100 \%$ Recommend dose of N supply through Vermicompost 
Table.2 Dry matter distribution (g) in different plant parts as 60 DAS as influenced by soybean varieties and fertilizer levels

\begin{tabular}{|c|c|c|c|c|c|c|c|c|c|c|c|c|}
\hline \multirow{3}{*}{$\begin{array}{l}\text { Fertilizer } \\
\text { level }(F)\end{array}$} & \multicolumn{3}{|c|}{ Leaves } & \multicolumn{3}{|c|}{ Stem } & \multicolumn{3}{|c|}{ Root } & \multicolumn{3}{|c|}{ Pod } \\
\hline & \multicolumn{2}{|c|}{ Variety (V) } & \multirow[t]{2}{*}{ Mean } & \multicolumn{2}{|c|}{ Variety (V) } & \multirow[t]{2}{*}{ Mean } & \multicolumn{2}{|c|}{ Variety (V) } & \multirow[t]{2}{*}{ Mean } & \multicolumn{2}{|c|}{ Variety (V) } & \multirow[t]{2}{*}{ Mean } \\
\hline & $\mathbf{V}_{1}$ & $\mathbf{V}_{2}$ & & $\mathbf{V}_{1}$ & $\mathbf{V}_{2}$ & & $\mathbf{V}_{1}$ & $\mathbf{V}_{2}$ & & $\mathbf{V}_{1}$ & $\mathbf{V}_{2}$ & \\
\hline $\mathbf{F}_{1}$ & 8.97 & 8.33 & 8.65 & 2.61 & 2.19 & 2.40 & 1.32 & 1.61 & 1.47 & 11.78 & 4.86 & 8.32 \\
\hline $\mathbf{F}_{2}$ & 7.33 & 7.65 & 7.49 & 2.19 & 2.07 & 2.13 & 1.25 & 1.18 & 1.22 & 11.22 & 4.75 & 7.99 \\
\hline $\mathbf{F}_{\mathbf{3}}$ & 7.09 & 6.16 & 6.62 & 2.18 & 1.88 & 2.03 & 1.15 & 1.06 & 1.11 & 9.74 & 4.58 & 7.16 \\
\hline $\mathbf{F}_{4}$ & 4.87 & 5.74 & 5.31 & 1.91 & 1.63 & 1.77 & 0.60 & 1.01 & 0.80 & 7.89 & 3.82 & 5.85 \\
\hline $\mathbf{F}_{5}$ & 3.28 & 4.90 & 4.09 & 1.10 & 1.65 & 1.37 & 0.57 & 0.96 & 0.77 & 5.67 & 4.26 & 4.97 \\
\hline \multirow[t]{2}{*}{ Mean } & 6.31 & 6.56 & 6.43 & 1.99 & 1.88 & 1.94 & 0.98 & 1.17 & 1.07 & 9.26 & 4.45 & 6.86 \\
\hline & $\mathbf{V}$ & $\mathbf{F}$ & $\mathbf{F} \times \mathbf{V}$ & $\mathbf{V}$ & $\mathbf{F}$ & $\mathbf{F} \times \mathbf{V}$ & $\mathbf{V}$ & $\mathbf{F}$ & $\mathbf{F} \times \mathbf{V}$ & $\mathbf{V}$ & $\mathbf{F}$ & $\mathbf{F} \times \mathbf{V}$ \\
\hline S.Em \pm & 0.28 & 0.44 & 0.62 & 0.09 & 0.14 & 0.20 & 0.05 & 0.07 & 0.10 & 0.30 & 0.47 & 0.67 \\
\hline C.D. $(5 \%)$ & NS & 1.30 & NS & NS & 0.42 & NS & 0.14 & 0.21 & NS & 0.89 & 1.40 & 1.98 \\
\hline C.V (\%) & & 16.65 & & & 17.91 & & & 16.51 & & & 16.84 & \\
\hline
\end{tabular}

NS- Non-Significant, RDF- Recommend dose of Fertilizer (40:80:25:12:20 kg /ha)

Factor I: Varieties

V1- JS-335

V2- SwarnaVasundhara
Factor II: Nutrient management practices

F1-125\% RDF

F2-100\% RDF

F3-75\% RDF

F4-50\% RDF

F5- $100 \%$ Recommend dose f N supply through Vermicompost 
Table.3 Dry matter distribution (g) in different plant parts at harvest as influenced by soybean varieties and fertilizer levels

\begin{tabular}{|c|c|c|c|c|c|c|c|c|c|c|c|c|}
\hline \multirow{3}{*}{$\begin{array}{l}\text { Fertilizer } \\
\text { level }(F)\end{array}$} & \multicolumn{3}{|c|}{ Leaves } & \multicolumn{3}{|c|}{ Stem } & \multicolumn{3}{|c|}{ Root } & \multicolumn{3}{|c|}{ Pod } \\
\hline & \multicolumn{2}{|c|}{ Variety (V) } & \multirow[t]{2}{*}{ Mean } & \multicolumn{2}{|c|}{ Variety (V) } & \multirow[t]{2}{*}{ Mean } & \multicolumn{2}{|c|}{ Variety (V) } & \multirow[t]{2}{*}{ Mean } & \multicolumn{2}{|c|}{ Variety (V) } & \multirow[t]{2}{*}{ Mean } \\
\hline & $\mathbf{V}_{1}$ & $\mathbf{V}_{2}$ & & $V_{1}$ & $\mathbf{V}_{2}$ & & $\mathbf{V}_{1}$ & $\mathbf{V}_{2}$ & & $V_{1}$ & $\mathbf{V}_{2}$ & \\
\hline $\mathbf{F}_{1}$ & 5.31 & 5.03 & 5.17 & 1.65 & 2.19 & 1.92 & 0.69 & 0.64 & 0.66 & 5.63 & 2.79 & 4.21 \\
\hline $\mathbf{F}_{2}$ & 4.35 & 4.67 & 4.51 & 1.31 & 1.99 & 1.65 & 0.65 & 0.65 & 0.65 & 5.45 & 2.67 & 4.06 \\
\hline $\mathbf{F}_{3}$ & 3.18 & 4.63 & 3.91 & 1.22 & 1.89 & 1.55 & 0.53 & 0.74 & 0.63 & 4.55 & 2.64 & 3.59 \\
\hline $\mathbf{F}_{4}$ & 3.09 & 4.55 & 3.82 & 1.07 & 1.95 & 1.51 & 0.43 & 0.79 & 0.61 & 4.50 & 2.35 & 3.42 \\
\hline $\mathbf{F}_{5}$ & 1.62 & 3.83 & 2.73 & 0.84 & 1.71 & 1.27 & 0.31 & 0.60 & 0.45 & 2.94 & 2.76 & 2.85 \\
\hline \multirow[t]{2}{*}{ Mean } & 3.50 & 4.54 & 4.03 & 1.21 & 1.95 & 1.58 & 0.52 & 0.68 & 0.60 & 4.61 & 2.64 & 3.63 \\
\hline & $\mathbf{V}$ & $\mathbf{F}$ & $\mathbf{F} \times \mathbf{V}$ & $\mathbf{V}$ & $\mathbf{F}$ & $\mathbf{F} \times \mathbf{V}$ & $\mathbf{V}$ & $\mathbf{F}$ & $\mathbf{F} \times \mathbf{V}$ & $\mathbf{V}$ & $\mathbf{F}$ & $\mathbf{F} \times \mathbf{V}$ \\
\hline S.Em \pm & 0.16 & 0.25 & 0.36 & 0.07 & 0.11 & 0.16 & 0.02 & 0.03 & 0.04 & 0.15 & 0.24 & 0.34 \\
\hline C.D. $(5 \%)$ & 0.48 & 0.76 & 1.07 & 0.22 & 0.34 & NS & 0.06 & 0.09 & 0.13 & 0.45 & 0.71 & 1.01 \\
\hline C.V (\%) & \multicolumn{3}{|c|}{15.49} & \multicolumn{3}{|c|}{17.77} & \multicolumn{3}{|c|}{12.88} & \multicolumn{3}{|c|}{16.17} \\
\hline
\end{tabular}

NS- Non-Significant, RDF- Recommend dose of Fertilizer (40:80:25:12:20 kg /ha)

Factor I: Varieties

V1- JS-335

V2- SwarnaVasundhara
Factor II: Nutrient management practices

F1-125\% RDF

F2-100\% RDF

F3-75\% RDF

F4-50\% RDF

F5- $100 \%$ Recommend dose of N supply through Vermicompost 
Table.4 Total dry matter production (g) leaf area index at various growth stages as influenced by soybean varieties fertilizer levels

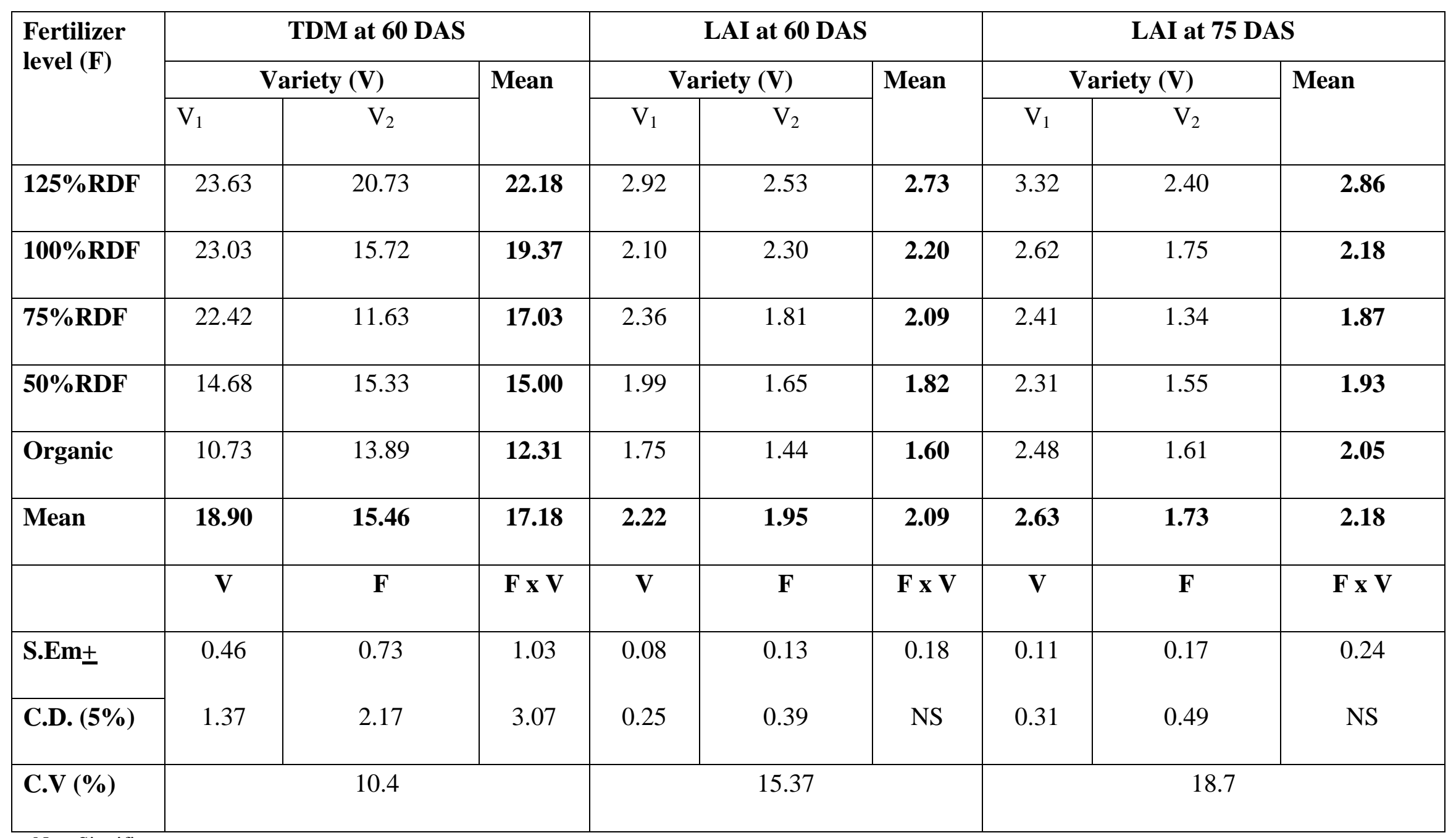

Non-Significant

Recommend dose of Fertilizer (40:80:25:12:20 kg N: $\mathrm{P}_{2} \mathrm{O}_{5}: \mathrm{K}_{2} \mathrm{O}: \mathrm{ZnSO}_{4}: \mathrm{S}$ per hectare + Rhizobium $\left.1.25 \mathrm{~kg} / \mathrm{ha}-1+\mathrm{PSB} 1.25 \mathrm{~kg} / \mathrm{ha}\right)$ 
Fig.1 Effect of varieties and fertilizer levels on total dry matter production

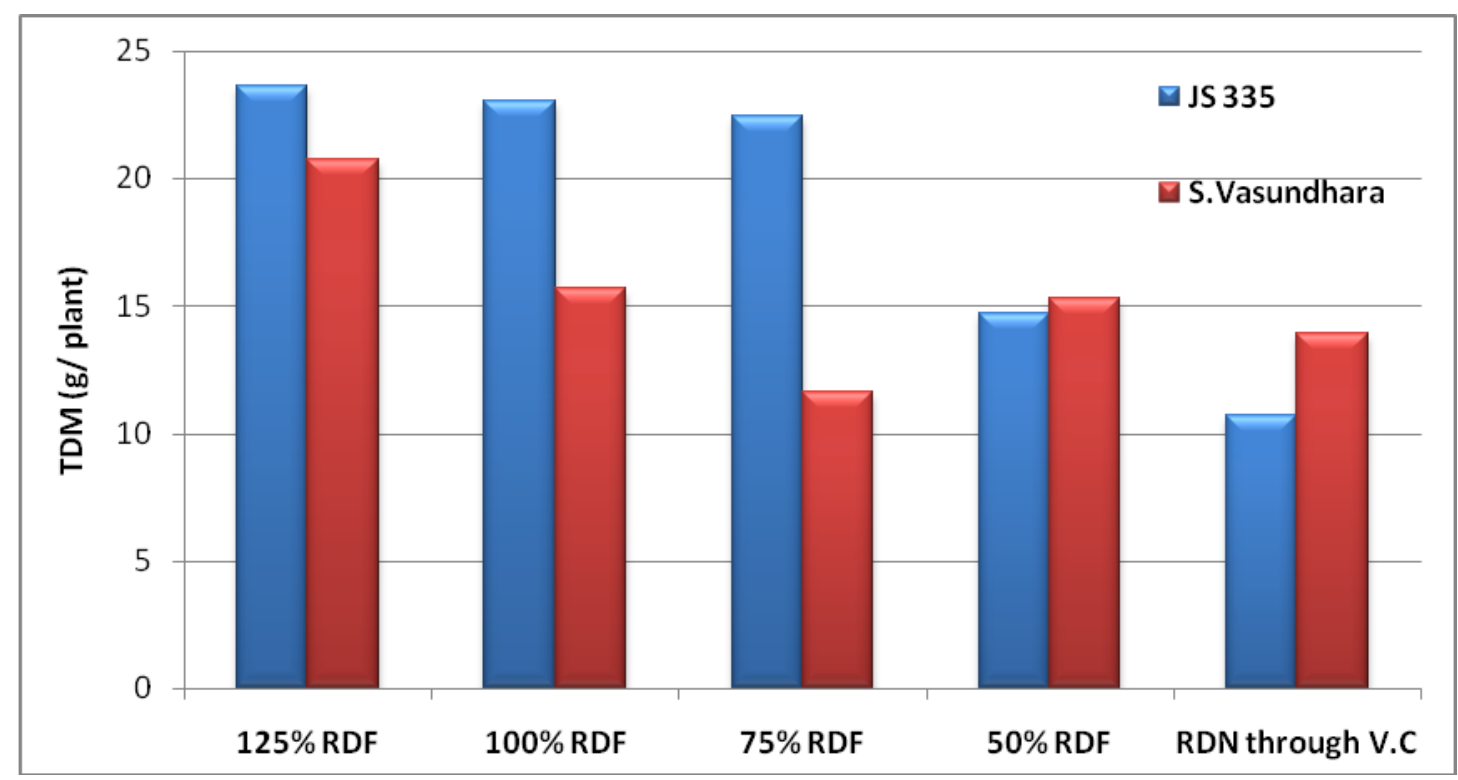

Fig.2 Effect of varieties and fertilizer levels on LAI at 60 and 75 DAS

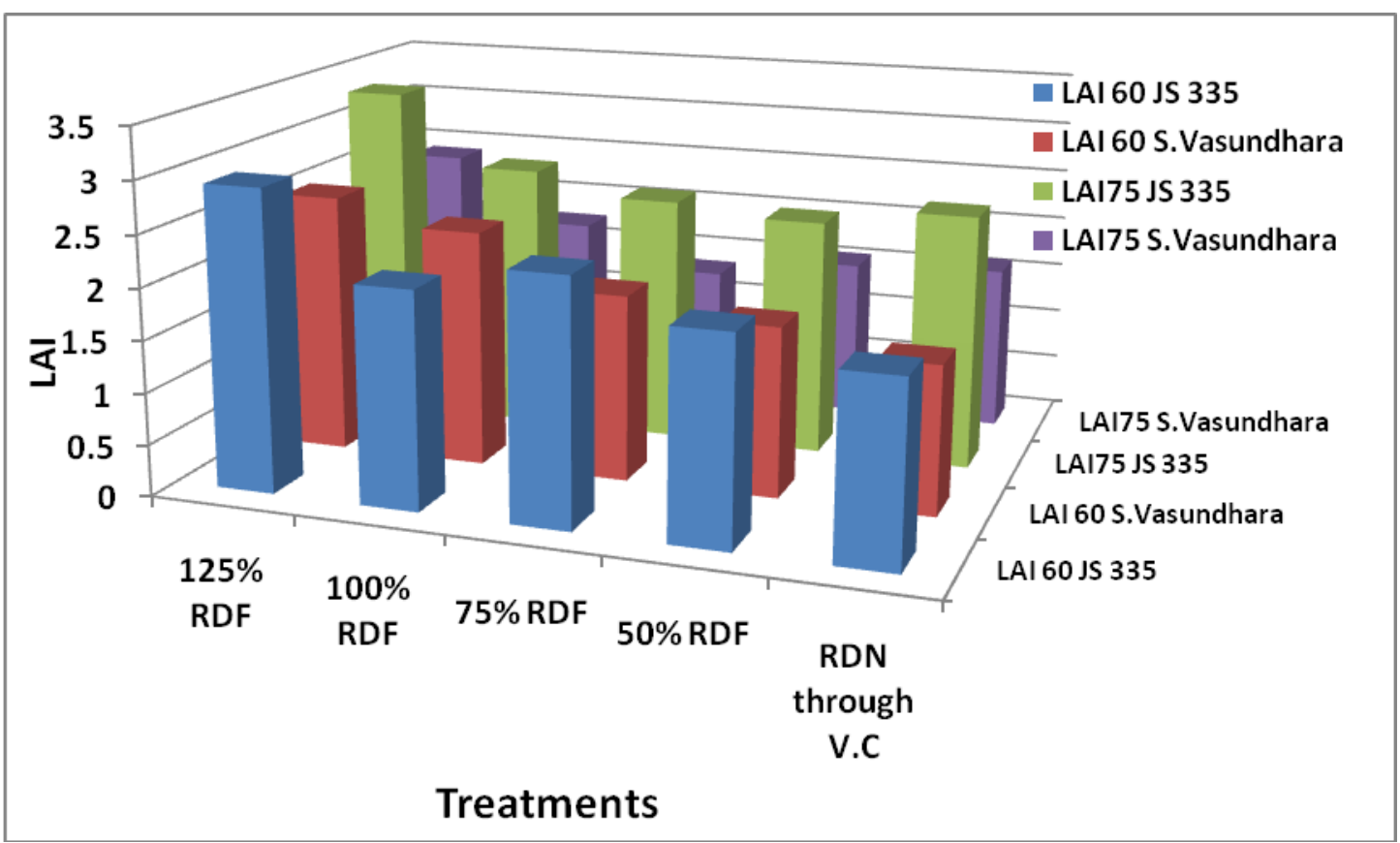

Among different fertilizer levels, application of 125 per cent of RDF recorded significantly higher dry matter in leaves $(5.17 \mathrm{~g} / \mathrm{plant})$ over other treatments but on par with 100 per cent $\mathrm{RDF}(4.51 \mathrm{~g} /$ plant $)$.With regard to interaction, application of 125 per cent RDF with JS 335 variety recorded significantly higher dry matter in leaves $(5.31 \mathrm{~g} /$ plant $)$ as compared to other treatment combinations but on par with 100per cent RDF with JS 335 and 125per cent,100per cent, 75per cent and 50 per cent RDF with Swarna Vasundhara. Swarna 
Vasundharadid not show any significant variation in leaf dry matter with variation in fertilizer levels.

Dry matter in stem at harvest (75DAS) was significantly influenced by varieties, different fertilizer levels but their interaction with fertilizer levels did not differ significantly (Table 3).Among the varieties Swarna Vasundhara recorded significantly higher dry matter in stem (1.95g/plant) over JS 335 (1.21 $\mathrm{g} /$ plant).Among different fertilizer levels, application of 125 percent of RDF recorded significantly higher dry matter in stem (1.92g/plant) over other treatments but on par with 100 per cent RDF.

The dry matter in root at harvest was significantly influenced by varieties, different fertilizer levels and their interactions (Table 3). Among the varieties, Swarna Vasundhara recorded significantly higher dry matter in roots $(0.68 \mathrm{~g} / \mathrm{plant})$ over JS-335 $(0.52$ $\mathrm{g} /$ plant). Among different fertilizer levels, application of 125 percent of RDF recorded significantly higher dry matter in roots (0.66g/Plant) over 100 per cent RDN through vermicompost but on par with all fertilizer levels. With regard to interaction, application of 50 per cent RDF with Swarna Vasundhara recorded significantly higher dry matter in roots $(0.79 \mathrm{~g} /$ plant $)$ as compared to other treatment combination but on par with 125 per cent RDF with JS 335 (0.69 g/ plant).

Dry matter in pod at harvest was significantly influenced by varieties, different fertilizer levels and their interactions (Table 3).Among the varieties JS-335 recorded significantly higher dry matter (4.61 g/plant) in pod over Swarna Vasundhara (2.64 g/plant). Among different fertilizer levels, application of 125 percent of RDF recorded significantly higher dry matter in pod (4.21 g/plant) over other treatments. Lowest dry matter in pod was recorded in 50 per cent RDF and 100 per cent
RDN through vermicompost. With regard to interaction, application of 125 per cent RDF with JS 335 recorded the significantly higher (5.63 g/plant) dry matter in pod as compared to other treatment combination but on par with 100per cent RDF with JS 335 $(5.45 \mathrm{~g} / \mathrm{plant})$.

The total dry matter (TDM) per plant was significantly influenced by varieties, different fertilizer levels and their interactions (Table 4). Result revealed that JS-335 recorded significantly higher total dry matter (18.90 g/plant) over Swarna Vasundhara (15.46 $\mathrm{g} /$ plant).Among different fertilizer levels application of 125 percent RDF recorded significantly higher total dry matter (22.18 g/plant) over other treatments. With regard to interaction TDM was significantly higher (23.63 g/plant) in variety JS 335 as compared to Swarna Vasundhara over other treatment combination but on par with 100 per cent RDF, 75 per cent RDF with JS 335 and 125 per cent RDF with Swarna Vasundhara.

Swarna Vasundhara did not show any significant difference in TDM with fertilizer levels. Leaf area index at 60 and 75 DAS varied significantly with varieties and different fertilizer levels but their interactions did not show significant effect(Table 4).Variety JS-335 recorded significantly higher leaf area index at 60 (2.22)and 75 DAS (2.63) as compared to Swarna Vasundhara at 60(1.95)and 75 DAS (1.73) respectively. Among different fertilizer levels, application of 125 per cent RDF recorded significantly highest leaf area index over all other treatments at 60 (2.73) and 75 DAS (2.86).

Application of 125 per cent RDF resulted in significant improvement in total dry matter accumulation over other treatments (Fig.1). Higher TDM was attributed to significantly higher height, number of leaves and LAI which contributed to the higher dry matter production. The better nutrient supply as 
evidenced by higher nutrient content in different plant parts at 60 and 75DAS resulted in significant increase in dry matter accumulation at different stages due to high accumulation of photosynthates because of efficient availability of energy sources i.e., ATP and NADP for which nitrogen, phosphorous and potassium elements were responsible (Thakure, 2009 and Saxena et al., 2013). Similar finding was reported by Vyas and Kushwah (2015).

There was no significant difference in growth performance in terms of plant height and number of leaves between JS 335 and Swarna Vasundhara. However JS 335 recorded significantly higher LAI at 60 and 75DAS resulting in significantly higher TDM as compared to Swarna vasundhara (Fig. 2). Contrastingly, Poornima et al., (2014) while evaluating the physiological basis of yield variation among the different vegetable genotypes have reported no significant difference in growth performance between JS 335 and Swarna Vasundhara. With regard to effect of interaction between variety and fertilizer levels on growth performance, JS 335 with 125 per cent RDF showed significantly higher TDM as compared to all fertilizer levels with Swarna Vasundhara. This may be because of production of significantly higher photosynthetic surface in terms of number of leaves and LAI resulting in better biomass production and accumulation in different parts. Soybean grown with 100 per cent RDN through vermicompost was found relatively less vigorous than those grown with fertilizer treatments as indicated by the moderate growth parameters. It is quite evident from the results that, when $\mathrm{N}$ was supplied through vermicompost, growth and development of soybean plants were moderate, which might be ascribed to slower mineralization of organic manures and non-availability of nutrients in adequate amounts especially during early stages of crop growth and similar result was reported by Ranjitha (2016).

Among the fertilizer levels application of 125per cent RDF showed better performance with respect to growth and yield, however it was on par with 100 per cent RDF. With regard to interaction, application of 100 per cent RDF with JS 335 variety was found better for northern dry zone of Karnataka. Swarna Vasundhara showed better growth with fertilizer levels did not show any better dry matter production and partitioning under the northern dry zone of Karnataka.

\section{References}

Cirak, O. M. S, Kenseroglu, K., Karaca, E. and Gulumser, A. 2006, Response of soybean to soil and foliar applied boron at different rates. Indian Journal of Agricultural Sciences, 76: (10): 603606.

Kumar, A. Prasad, S. and Kumar, S. B., 2006, Effect of boron and sulphur on performance of gram. Indian Journal of Agronomy, 51(1): 57-59.

Millhollon, E. P. 1985, The relationship between photosynthesis and the capacity for nitrogen fixation in soybean. Dissertation Abstracts, 45 (4): 98- 101.

Panse, V.G. and Sukhatme, P.V., 1967, The application of genetics to plant breeding. The inheritance of quantitative characters and plant breeding Journal of Genetics, 40: 283302.

Poornima, R., Koti, R. V., and Nair, M. R., 2014, Physiological basis of yield variation in vegetable soybean and organoleptic test for acceptance. Plant Archives, 14 (1): 51-54.

Ranjitha, B. M., 2016, Effect of soil test based INM practices on the performance of chilli (Capsicum annuum L.). M.Sc. 
Thesis, University of Horticultural Sciences, Bagalkot.

Saxena, S. C., Nainwal, R. C. and Joshi, A., 2013, Optimization of nutritional levels for newly released soybean [Glycine $\max ($ L.) merrill] varieties in mollisols of Uttarakhand. Soybean Research, 11(2): 43-54.

Thakur, H. S. and Girothia, O. P., 2010, Response of soybean [Glycine max (L.) Merrill] and chickpea (Cicerarietinum) cropping sequence to phosphorus nutrition. Soybean Research, 8: 13- 19.
Thakur, H. S., Raghuwanshi, S. R. S. and Raghuwanshi, O. P. S., 2009, Integrated nutrient management in soybean [Glycine $\max ($ L.) Merrill]. Soybean Research, 7: 16-20.

UAS Dharwad, 2016, Package of Practices, pp 163-171. (website: www.uasd.edu.in).

Vyas, A. K., Billore, S. D., Joshi, O. P. and Pachlania, N. K., 2007, Influence of balanced nutrition on productivity of soybean. Soybean Research, 5: 21-25.

\section{How to cite this article:}

Vijayalakshmi Patil, Shankar Meti, C. P. Mansur, E. Rajashekhara, Itagi Prabhaker, H. P. Hadimani and Kaviraja H. 2017. Nutritional Studies on Vegetable Soybean [Glycine max (L.) Merrill], in Northern Dryzone of Karnataka, India. Int.J.Curr.Microbiol.App.Sci. 6(12): 53645374. doi: https://doi.org/10.20546/ijcmas.2017.612.501 